\title{
Strategi Manajemen Menghadapi Risiko Operasional Pada Pt Bank Pembiayaan Rakyat Syariah (BPRS) Haji Miskin Pandai Sikek
}

\author{
Ifelda Nengsih 1 , Dina Meidani2 \\ IAIN Batusangkar, Indonesia ${ }^{1}$
}

\author{
$\varangle$ Corresponding Author: \\ Nama Penulis: Ifelda Nengsih \\ E-mail: ifeldanengsih@iainbatusangkar.ac.id
}

\begin{abstract}
PT Bank Pembiayaan Rakyat Syariah (BPRS) Haji Miskin Pandai Sikek is faced with operational risks such as data input errors by bank employees, money laundering, counterfeit money, customer dishonesty, fraud or data manipulation, and several other risks that may occur. Therefore, PT BPRS Haji Poor needs to manage these operational risks. The results of the study show that operational risk management at the Haji Poor Pandai Sikek BPRS has implemented risk management in accordance with POJK regulations No.23/POJK.03/2018 regarding the implementation of risk management for Islamic People's Financing Banks. Identification of operational risk caused by internal risk, $H R$ risk, technology and system risk, legal risk and external risk. Risk management is carried out following a risk management process starting from identification, risk measurement, risk monitoring and risk control activities that occur at the Haji Poor Pandai Sikek BPRS. The strategy is to improve the supervisory function and conduct an internal audit.
\end{abstract}

Keywords: Strategy, Management, Operational Risk, BPRS Haji Poor Smart Sikek

\begin{abstract}
Abstrak: PT Bank Pembiayaan Rakyat Syariah (BPRS) Haji Miskin Pandai Sikek dihadapkan pada risiko operasional seperti kesalahan penginputan data oleh karyawan bank, pencucian uang, terdapat uang palsu, ketidak jujuran nasabah, penipuan atau manipulasi data, dan beberapa risiko lainnya yang akan mungkin terjadi. Oleh karena itu, PT BPRS Haji Miskin perlu melakukan manajemen terhadap risiko operasional tersebut. Hasil penelitian menunjukan bahwa Manajemen risiko operasional di BPRS Haji Miskin Pandai Sikek telah menerapkan manajemen risiko sesuai dengan peraturan POJK No.23/POJK.03/2018 tentang penerapan manajemen risiko bagi Bank Pembiayaan Rakyat Syariah. Identifikasi risiko operasional yang disebabkan risiko internal, risiko SDM, risiko teknologi dan sistem, risiko hukum dan risiko eksternal. Pengelolaan risiko yang dilakukan mengikuti proses manajemen risiko yang dimulai dari aktifitas identifikasi, pengukuran risiko, pemantauan risiko dan pengendalian risiko yang terjadi di BPRS Haji Miskin Pandai Sikek. Strategi yang dilakukan adalah dengan meningkatkan fungsi pengawasan serta melakukan internal audit.
\end{abstract}

Kata kunci: Strategi, Manajemen, Risiko Operasional, BPRS Haji Miskin Pandai Sikek 


\section{PENDAHULUAN}

Salah satu kegiatan usaha yang paling dominan dan sangat dibutuhkan keberadaanya didunia ekonomi adalah kegiatan usaha lembaga keuangan perbankan, oleh karena fungsinya sebagai pengumpul dana yang sangat berperan demi menunjang pertumbuhan ekonomi suatu bangsa. Sebagai alat penghimpun dana, lembaga keuangan ini mampu melancarkan gerak pembangunan dan penyaluran dananya keberbagai proyek penting diberbagai sektor usaha. Demikian pula lembaga keuangan ini dapat menyediakan dana bagi pengusaha atau kalangan masyarakat yang membutuhkan dana bagi kelangsungkan usahanya. Hal ini menunjukan kinerja perbankan syariah di Indonesia sudah baik dalam waktu yang relatif singkat. (Hamid, 2008, p. 38)

Berdasarkan Salinan Peraturan Otoritas Jasa Keuangan Republik Indonesia (SPOJK) Nomor 23/POJK.03/2018 tentang penerapan manajemen risiko bagi Bank Pembiayaan rakyat Syariah. Bank Pembiayaan Rakyat Syariah (BPRS) adalah Bank Syariah yang dalam kegiatannya tidak memberikan jasa dalam lalu lintas pembayaran.

Bank Pembiayaan Rakyat Syariah (BPRS) tidak dapat dikonversi menjadi Bank Pengkreditan Rakyat (BPR). Bank Pembiayaan Rakyat Syariah tidak diizinkan untuk membuka kantor cabang, kantor perwakilan, dan jenis kantor lainya di luar negeri. Bank Pembiayaan Rakyat Syariah hanya dapat didirikan dan/atau dimiliki oleh: 1. Warga negara Indonesia atau badan hukum indonesia yang seluruh pemiliknya warga negara Indonesia, 2. Pemerintah daerah, dan 3. Dua pihak atau lebih sebagaimana dimaksud dalam angka 1 dan angka 2. Bentuk Badan Hukum Bank Pembiayaan Syariah adalah Perseroan Terbatas (PT). dalam struktur Bank Pembiayaan rakyat Syariah (BPRS) terdapat Dewan Pengawas yang bertugas memberikan nasihat dan saran kepada serta mengawasi kegiatan Bank Pembiayaan Rakyat Syariah (BPRS) agar selalu sesuai dengan prinsip syariah. (Subekti, 2020)

Di dalam sebuah jurnal dikatakan untuk menciptakan risiko yang baik, pihak BPRS perlu untuk mengetahui risiko apa yang terjadi, salah satunya risiko operasional. Risiko operasional adalah risiko kerugian yang diakibatkan oleh proses internal, kesalahan manusia, kegagalan sistem, dan/ atau adanya 
kejadian-kejadian eksternal di dalam BPRS ataupun dunia Perbankan. (Jelita \& Shofawati, 2019, p. 72)

Penerapan manajemen risiko operasional di BPRS minimal mencangkup beberapa hal seperti: pengawasan aktif dewan komisaris, direksi dan dewan pengawas syariah, kecukupan kebijakan, prosedur, dan penetapan limit risiko, kecukupan proses identifikasi yang menyeluruh. Menajemen risiko operasional untuk meminimalkan kemungkinan dampak negatif dari tidak berfungsinya proses internal, kesalahan manusia, kegagalan sistem dan kejadian-kejadian eksternal. (Nurapiah, 2019, pp. 66-67)

Salah satu perbankan yang juga turut menerapkan manajemen risiko operasional adalah BPRS Haji Miskin Pandai Sikek, beroperasi semenjak 1 April 2006. Berkantor pusat di Pandai Sikek, modal disetor BPRS Haji Miskin adalah Rp. 1.000.000.000,- (satu miliyar rupiah) atas nama 75 orang pemegang saham masyarakat Pandai Sikek dan Padang laweh, baik yang bermukim di kampung halaman maupun mereka yang menetap di perantauan seperti Jakarta, Pekanbaru, Padang dan Batusangkar. BPRS Haji Miskin diresmikan 30 Maret 2006 oleh Direktur Perbankan Syariah Bank Indonesia Jakarta, Harisman, berdasarkan keputusan Gubernur bank Indonesia No.8/24IKEP.GBI/2006. Dari tahun ke tahun membuat BPRS Haji Miskin terus meningkatkan menajemennya untuk meminimalisir dan mengelola risiko yang salah satunya adalah risiko operasional.

Berdasarkan hasil wawancara dengan Funding Officer di BPRS Haji Miskin yaitu Ibu Misrina, Faktor eksternal yaitu mencankup ketidak jujuran nasabah, penipuan atau manipulasi data, dan kerja sama yang kurang baik. Apalagi di masa pandemi ini banyak nasabah yang kesulitan dalam bidang pariwisata dan banyaknya nasabah yang membayar setenggah dan ada juga nasabah yang membayar sepenuhnya. Ada juga kesalahan dalam faktor internal ini seperti pihak karyawan yang kurang teliti dalam mengumpilkan data nasabah sehingga perlu dua kali dalam mengumpulkan data, kesalahan analisis dari marketing, terdapat uang palsu, melakukan pencucian uang, analisis nilai jaminan yang tidak sesuai. Kurangnya pengetahuan nasabah akan proses akad serta ketidak sesuaian perhitungan dengan persyaratan syariah. adanya kesalahan pada 
Strategi Manajemen Menghadapi Risiko Operasional Pada Pt Bank Pembiayaan Rakyat Syariah (Bprs) Haji Miskin Pandai Sikek proses pengimputan data oleh karyawan dan kesalahan yang disebabkan karena adanya ganguan sistem seperti komputer down atau jaringan yang error pada saat pengimputan dan bencana Covid-19 saat ini. Tentu ini mempengaruhui operasional di BPRS haji miskin yang berefek kepada pengimputan data nasabah yang terhambat, pengimputan keuangan yang dilakukan kepada rekening nasabah oleh karyawan akibat kekurangan peryaratan yang di minta dan lain sebagainya. Dan adanya risiko tersebut maka perlu dilakukan strategi manajemen (Masrina, 2020)

Dalam kasus yang terjadi pada PT. BPRS Haji Miskin Pandai Sikek, bahwa terdapat kesalahan manajemen operasional. Berdasarkan identifikasi masalah diatas, dalam mempertimbangkan manajemen risiko operasional ini menjadi sangat penting, sehingga nantinya BPRS Haji Miskin Pandai Sikek dapat meninimalisir risiko yang terjadi dan juga mendapatkan manfaatnya. Pertimbanganya yaitu menajemen risiko operasional, risiko yang diakibatkan kurangnya informasi dan sistem pengawasan. Apa saja jenis-jenis risiko operasional yang terdapat di PT Bank Pembiayaan Rakyat Syariah (BPRS) Haji Miskin Pandai Sikek?, Bagaimana Strategi Manajemen menghadapi Risiko Operasional yang disebabkan oleh faktor internal dan faktor eksternal pada PT Bank Pembiayaan Rakyat Syariah (BPRS) Haji Miskin Pandai Sikek ?

\section{METODE PENELITIAN}

\subsection{Jenis Penelitian}

Jenis penelitian yang digunakan dalam penelitian ini adalah penelitian lapangan (Field Research), mengunakan metode kualitatif dengan pendekatan deskriptif. Menurut Sugiyono (2016:2), penelitian lapangan (Field Research) merupakan penelitian yang dilakukan dengan mengumpulkan data dan informasi yang diperoleh langsung dari responden, dan mengamati secara langsung tugas-tugas yang berhubungan dengan penelitian yang dilakukan.

\subsection{Latar Dan Waktu Penelitian}

Penulis melakukan penelitian di kantor PT Bank Pembiayaan Rakyat Syariah (BPRS) Haji Miskin Pandai Sikek, pada bulan Oktober sampai dengan 
Desember 2020.

\subsection{Instrumen Penelitian}

Intrumen penelitian adalah alat bantu yang dipilih dan digunakan oleh peneliti dalam kegiatan mengumpulkan agar kegiatan tersebut menjadi sistematis dan dipermudah olehnya. Instrumen pengumpulan data adalah cara yang dan peneliti untuk mengumpulkan data. Instrumen utama dari penelitian ini adalah peneliti sendiri, sedangkan instrument tambahan lainya yang berguna untuk menjalang kelengkapan data adalah Kamera, Field note, dan perekam.

\subsection{Sumber Data}

Sumber data yang digunakan dalam penelitian ini adalah data primer dan data sekunder. 1) Sumber data primer adalah suatu data yang berasal dari pihak yang bersangkutan atau langsung dari responden. Dalam penelitian ini sumber data primer diperoleh melalui wawancara langsung dengan karyawan di bidang Manajemen Kepatuhan, Direktur Kepatuhan dan yang diperiksa kepatuhan di PT BPRS Haji Miskin Pandai Sikek. 2) Data sekunder yaitu data yang diperoleh/dikumpulkan dan disatukan oleh studi-studi sebelumnya atau yang diterbitkan oleh berbagai instansi lain. Data sekunder dalam penelitian ini diperoleh dari studi pustaka, buku-buku, dan sumbersumber lainya yang berkaitan dengan strategi manajemen terhadap risiko operasional pada PT BPRS Haji Miskin Pandai Sikek

\subsection{Teknik Pengumpulan Data}

Dalam penelitian ini, teknik pengumpulan data yang penulis gunakan yaitu wawancara. Wawancara adalah sebuah teknik pengumpulan data dengan cara melakukan kegiatan tanya jawab yang memiliki maksud, dalam hal ini penulis melakukan wawancara dengan mengajukan pertanyaan lisan dan tulisan kepada sumber data yaitu karyawan di bidang Manajemen Kepatuhan, Direktur Kepatuhan dan yang diperiksa kepatuhan di PT BPRS Haji Miskin Pandai Sikek.

\subsection{Teknik Analisa Data}

Didalam melakukan analisis data peneliti mengacu kepada beberapa tahapan yang dijelaskan Miles dan Huberman (1992:15-19) yang terdiri dari 
: 1) Pengumpulan Data, yaitu mengumpulkan data di lokasi penelitian dengan melakukan observasi, wawancara, dan dokumentasi dengan menentukan strategi pengumpulan data yang dipandang tepat dan untuk menentukan fokus serta pendalaman data pada proses pengumpulan data berikutnya.2) Reduksi Data, yaitu sebagai proses seleksi, pemfokuskan, pengabstrakan, transformasi data dan kasar yang ada di lapangan langsung, dan ditentukan pada waktu pengumpulan data, dengan demikian reduksi data dimulai sejak penelitian memfokuskan wilayah penelitian. 3) Penyajian Data, yaitu rangkaian organisasi informasi yang memungkinkan penelitian dilakukan. Penyajian data diperoleh berbagai jenis, jaringan kerja, keterkaitan kegiatan atau tabel. 4) Penarikan Kesimpulan, yaitu dalam pengumpulan data, peneliti harus mengerti dan tanggap terhadap sesuatu yang diteliti langsung di lapangan dengan menyusun pola-pola pengarahan dan sebab akibat.

\subsection{Teknik Keabsahan Data}

Trianggulasi adalah cara yang paling umum digunakan dalam penjaminan vasilitas data dalam penelitian kualitatif, triggualasi merupakan teknik pemeriksaan keabsahan data dengan memanfaatkan sesuatu yang lain diluar data itu untuk keperluan pengecekan data atau sebagai pembandingan terhadap data itu. Menurut Sugiyono (2006:267), vasilitas merupakan "derajad ketetapan antara data yang terjadi pada objek penelitian dengan daya yang dapat dilaporkan oleh penelitian".

Keabsahaan data dalam penelitian ini menggunakan trianggulasi, Sugiyono (2006:273-273), menjelaskan ada tiga macam trianggulasi. Ketiga trianggulasi tersebut yaitu trianggulasi sumber, pengumpulan data, dan waktu.

Penjelasan dari trianggulasi sumber adalah trianggulasi yang digunakan untuk menguji kredibilitas data dengan cara mengecek data yang telah diperoleh melalui beberapa sumber.

Berdasarkan pemaparan di atas penelitian ini menggunakan trianggulasi sumber data. Trianggulasi sumber data yang berupa wawancara secara tidak terstruktur dengan narasumber secara langsung dengan Manajemen 
Kepatuhan, direktur kepatuhan dan diperiksa kepatuhan di PT Bank Pembiayaan Rakyat Syariah (BPRS) Haji Miskin Pandai Sikek.

\section{HASIL PENELITIAN}

Pelaksanaan manajemen risiko di BPRS Haji Miskin telah mengacu kepada Peraturan Otoritas Jasa Keuangan (POJK) No.23/POJK/2018 tentang penerapan manajemen risiko bagi bank pembiayaan rakyat syariah. praktik manajemen risiko menjadi perhatian besar sehingga banyak perbankan yang mengalami kesulitan likuiditas akibat kurangnya kehati-hatian dalam melaksanakan operasional perbankan. Berdasarkan POJK tersebut BPRS Haji menetapkan risiko dapat diklasifikasikan berdasarkan penyebab terjadinya, yaitu sebagai berikut:

a. Risiko Operasional, penyebab terjadinya risiko ini adalah pertama manusia, risiko yang disebabkan atau terjadi karena adanya pelanggaran yang dilakukan oleh karyawan (lalai dan ceroboh) contohnya tanda tanggan dipalsukan oleh karyawan. Yang kedua yaitu risiko yang disebabkan karna kesalahan proses contohnya kesalahan input data oleh karyawan. Yang ketiga risiko yang disebakan karena adanya gangguan sistem contohnya komputer down/hang. Yang terakhir yaitu faktor atau kejadian eksternal yang mengakibatkan kerugian bagi perusahaan contohnya banjir, gempa bumi. Kelalaian terhadap penerapan manajemen risiko operasional akan berdampak kepada pegawai, nasabah dan juga perusahaan.

b. Risiko Kredit, penyebab terjadinya risiko ini adalah pertama risiko yang timbul akibat kegagalan dari pihak lain dalam memenuhui kewajibanya, kedua resiko kredit dapat terjadi pada aktifitas pembiayaan, treasuri dan investasi, dan kegagalan client dalam membayar ijarah, istishna serta mengirimkan komoditi yang sudah dibeli (salam).

c. Risiko Kepatuhan, penyebab terjadinya risiko ini adalah risiko kepatuhan terjadi karena adanya pelanggaran terhadap ketentuan dan peraturan perundang-undangan yang berlaku yang dapat menyebabkan timbulnya kerugian finansial, risiko hukum, dan risiko reputasi. sebagai contoh dari risiko kepatuhan adalah bank tidak mengirimkan laporan tepat waktu 
Strategi Manajemen Menghadapi Risiko Operasional Pada Pt Bank Pembiayaan Rakyat Syariah (Bprs) Haji Miskin Pandai Sikek sehingga harus membayar sejumlah denda. Contoh lainnya adalah bank tidak secara utuh mengikuti prosedur seperti yang diterapkan oleh regulator.

d. Risiko Likuiditas, penyebab terjadinya risiko ini adalah yang pertama tim analisa yang kurang mampu memberikan detail dalam hal analisis dari segi aset. Bila kondisi ini tidak segera diatasi, maka akan mengakibatkan risiko likuiditas perusahaan menjadi parah. Yang kedua adanya keterlambatan arus kas sehingga aktiva lancar tidak bisa melampaui nilai kewajiban lancar perusahaan. Hal tersebut akan mudah terlihat jika sudah melakukan perhitungan pada rasio likuiditas.

Berdasarkan fokus pemersalahan yang penulis teliti maka hasil penelitian ini mengemukakan bahwa :

1. Risiko operasional pada BPRS haji miskin Jenis-jenis risiko operasional yang dihadapi oleh BPRS haji misikin adalah :

a. Risiko internal, karena adanya kesalahan pada proses pengimputan data oleh karyawan, kesalahan analisis dari marketing, terdapat uang palsu, melakukan pencucian uang

b. Risiko sumber daya manusia, pada BPRS Haji Miskin terjadinya Fraud karena salah seorang karyawan yang dianggap memiliki kecerdasan dalam mengelola nasabah sehingga pihak BPRS memberikan wewenang besar kepada karyawan yang memberikan kemudahan untuk melakukan berbagai manipulasi transaksi. Akibatnya, karyawan kurang teliti pada saat mengumpulkan data nasabah sehingga perlu kerja dua kali dalam mengumpulkan data nasabah, analisis nilai jaminan yang tidak sesuai.

c. Risiko sistem dan teknologi, pada BPRS Haji Miskin yaitu kesalahan yang disebabkan karena adanya ganguan sistem seperti komputer down atau jaringan yang error pada saat pengimputan.

d. Risiko hukum

e. Risiko eksternal, kurangnya pengetahuan nasabah akan proses akad serta ketidak sesuaian perhitungan dengan persyaratan syariah. bencana alam yang terjadi sekarang ini yaitu Covid-19.

Resiko diatas merupakan jenis risiko operasional yang terjadi di BPRS haji miskin dan merupakan risiko yang utama. 
2. Strategi penaganan risiko operasional untuk mengatasi risiko yang ada pada BPRS haji miskin di atas, maka strategi yang digunakan adalah :

a. Identifikasi Risiko, pada tahapan ini dilakukan untuk mengidentifikasi risiko kemungkinan risiko yang akan terjadi atau dialami.

b. Asesmen Risiko, pada tahapan ini perusahaan atau organiasasi akan memberikan penilaian terhadap kemungkinan kerugian yang didapatkan. Dengan menilai kerugian dari identifikasi masalah yang dapat terjadi bisa memudahkan perusahaan dalam mengambil strategi penanganan yang baik dan efektif sehingga resiko kerugian tidak dapat dihindari namun bisa lebih diminimalisir.

c. Respon Risiko, cara ini juga memudahkan pemimpin perusahaan dalam pengambilan kebijakan atau strategi untuk mengatasi situasi yang ada. Berikut ini respon risiko yang dapat dilakukan yaitu risk avoidance: mengambil kebijakan untuk menghentikan kegiatan yang berpotensi menyebabkan risiko masalah, risk reduction: mengambil tindakan mengurangi kemungkinan dampak dengan mengendalian bagian internal perusahaan, risk sharing of transfer: mengambil tindakan menstranfer beberapa risiko melalui asuransi, outsourcing atau hedging, risk acceptance: tidak mengambil tindakan apapun untuk mengatasi risiko atau dengan kata lain menerima risiko tersebut terjadi dan yang terakhir create a risk management plan: membuat penanggulangan risiko yang tepat untuk masing-masing kategori.

d. Implementasi, yaitu melaksanakan seluruh metode yang telah direncanakan dengan tujuan untuk mengurangi dan menanggulangi pengaruh dari setaip risiko yang ada. Yang terakhir yaitu dengan tahap Evaluasi dan Review.

e. Biasanya akan dibentuk pertahanan yang disebut three lines of defense. yaitu pertahanan lapis pertama berfungsi sebagai mekanismen control preventif, pada pertahanan lapisan kedua berfungsi sebagai mekanisme control detekif, Risk Management, legal dan compliance dan pertahana lapis ketiga berfungsi sebagai mekanisme control korektif. 
Tentu ini mempengaruhui operasional di BPRS haji miskin yang berefek kepada pengimputan data nasabah yang terhambat, pengimputan keuangan yang dilakukan kepada rekening nasabah oleh karyawan akibat kekurangan peryaratan yang di minta dan kepatuhan-kepatuhan terhadap SOP (Standar Operasional Prosedur) operasional harus terpanuhi. SOP yang diterapkan BPRS Haji Miskin Pandai Sikek terhadap nasabah sesuai dengan ketentuan OJK yang ada dan aturan yang telah ditetapkan. Dimana dijelaskan dalam POJK N0.1/POJK.07/2013 tentang perlindungan konsumen sektor jasa keuangan. Yang mana di jelaskan pada pasal 1 ayat 3 yaitu konsumen adalah pihak-pihak yang menempatkan dananya dan/atau memanfaatkan pelayanan yang tersedia di lembaga jasa keuangan antara lain nasabah pada perbankan, permodalan di pasar modal, pemegang polis pada perasuransian, dan peserta pada dana pension, berdasarkan perundang-undangan di sektor jasa keuangan dan pada pasal 2 perlindungan konsumen menerapkan prinsip yaitu: transparansi, perlakuan yang adil, keandalan, kerahasiaan dan keamanan data/informasi konsumen, dam penanganan pengaduan serta penyelesaian sangketa konsumen secara sederhana, cepat dan biaya terjangkau (Peraturan Otoritas Jasa Keuangan, No.1/P0JK.07/2013, p. 1).

Dalam manajemen risiko operasional ada bagian seperti internal audit, direksi dan juga dewan pengawas serta kepala bagian-bagian operasional seperti teler. Dewan direksi mempunyai tugas untuk menetapkan bahwa risiko perbankan dalam menjalankan bisnis diatur dalam suatu tata cara yang efektif. Dalam pelaksanaan tugas tersebut dibutuhkan Pengawasan aktif dari dewan komisaris, dewan direksi dan oleh personil manajemen risiko yang terkait yang dipilih oleh bank. Penetapan kebijakan prosedur untuk menentukan batas untuk risiko yang dilaksanakan oleh bank. Penetapan prosedur untuk mengidentifikasi, mengukur, memantau, dan mengendalikan resiko. Penetapan dari suatu struktur pengawasan intern untuk mengatur resiko. Dalam memenuhi kewajibannya sebagai direksi, tugas dan tanggung jawab direksi salah satu sebagai berikut: Merumuskan dan mengusulkan kebijaksanaan umum bank untuk masa yang akan datang yang disetujui oleh dewan komisaris serta disahkan dalam RUPS agar tercapai tujuan serta kontinuitas operasional perusahaan; Menyusun dan 

mengusulkan Rencana Anggaran Perusahaan dan rencana kerja untuk tahun buku yang baru disetujui oleh dewan komisaris dan lain-lain. (Wardiah, 2013, p. 120) Dalam menjalankan tugasnya direksi harus memperhatikan beberapa prinsip-prinsip tanggung jawab direksi dalam menjalankan perseroan yakni duty of skill and care (prinsip kehati-hatian dalam tindakan direksi), duty of loyalty (itikad baik dari direksi semata-mata demi tujuan perseroan) dan no secret profit rule doctrine of corporate opportunity (tidak menggunakan kesempatan pribadi atas kesempatan milik atau peruntukan bagi perseroan) serta memiliki tugastugas dan kewajiban yang berdasarkan undang-undang (statutory duty). (Siregar, Suhaidi, \& Laviza, 2014, p. 175). Direksi BPRS Haji Miskin selaku komponen utama yang menetapkan strategi manajemen risiko terhadap risiko operasional sudah menjalankan dengan baik untuk meminimalisir risiko yang terjadi, langkah yang dilakukan meliputi fungsi pengawasan yang lebih diperketat, control terhadap atasan dan bawahan, pelatihan karyawan dan memaksimalkan kemampuan karyawan pada bidang masing-masing. strategi manajemen dalam menghadapi risiko operasional dalam faktor internal dan eksternal di BPRS Haji Miskin berada pada fungsi pengawasan yang diperketat. Strategi manajemen dalam menghadapi risiko operasional dalam faktor internal dan eksternal di BPRS Haji Miskin ada di fungsi pengawasan yang lebih diperketat. Strategi yang dilakukan manajemen menghadapi resiko operasional adalah dengan fokus pada dua faktor tersebut, mengoptimalkan controlling bagi segenap pegawai (internal) dan juga mengoptimalkan controlling bagi nasabah (eksternal). Lalu pihak BPRS akan mengevaluasi dari faktor-faktor yang timbul sehingga menimbulkan risiko operasional yang biasanya dilakukan mingguan maupun bulanan sekali dan akan melakukan internal audit kinerja oleh karyawan yang dipimpin oleh Direksi dan juga dewan pengawas sebelum di lanjutkan ke atas. Dengan fungsi pengawasan yang melekat serta pengawasan Internal audit, dengan aktifnya internal audit dalam melakukan pengecekanpengecekan, setiap hari dilakukan pengawasan terhadap kas tersebut didalam manajemen operasional dan dilapangan kita melakukan print buku dari nasabah dan control kembali buku tabungan nasabah, fungsi pengawasan itu mesti di pekertat lagi. Cara menanggulangi risiko yang terjadi pada umumnya yaitu 

dengan melakukan pengawasan yang lebih ketat terhadap nasabah dan melakukan edukasi kepada nasabah. Juga memberikan edukasi kepada karyawan, pihak pusat juga akan memonitor dan mereview kepada kantor untuk melakukan pemantauan risiko- risiko yang terjadi. Program khusus yang diterapkan BPRS Haji Miskin Pandai Sikek dalam menghadapi risiko operasional yang mulai tahun 2020 yang disebut dengan program rencana tindak, dan hanya menerapkan tiga manajemen resiko dalam program tersebut.

Dalam menangulanggi risiko BPRS Haji Miskin Pandai Sikek masih ditanggani oleh Direksi BPRS, yang disebabkan lembaga BPRS saat ini belum membentuk satuan kerja khusus untuk menangani risiko atau penanganan eksekutif. BPRS dalam meminimalisir risiko yang terjadi dengan cara menjaga ketentuan dan aturan terhadap pelayanan ke nasabah, menjaga likuiditas, dapat memenuhui ketentuan jangka pendek, memenuhui aturan-aturan perbankan, menjaga rahasia bank, menjaga rasia nasabah dan menjaga ketentuan interen seperti arus menjaga kas, likuiditas, rasia bank dan segala ketentuan-ketentuan sesuai dengan aturan yang diterapkan oleh OJK. Adapun cara yang dilakukan oleh pihak BPRS Haji Miskin dalam menangulanggi risiko jika adanya kesalahan pada proses pengimputan data oleh karyawan, akan diketahui oleh bagian operasionalnya. Ketika ada transaksi tidak langsung diverifikasi dan akan di cek oleh back officenya seperti tanda tanggan saat akan mengambil tabungan, vouchervoucher juga akan di cek kembali. BPRS juga akan memberikan sanksi, mulai dari memberikan teguran secara lisan, kalau kesalahan yang fatal maka akan diberikan sanksi berupa materi atau surat asli oleh BPRS. Kesalahan yang disebabkan karena adanya ganguan sistem seperti komputer down, biasanya akan menghubungi vendor jika terjadi kesalahan sistem. Jika kesalahan sistem tersebut dapat kita selesaikan sendiri kita lakukan perbaikan manual agar nasabah tidak menunggu lama, kecuali pada jaringan yang terkendala akan susah karena kita mengunakan vendor lain. Jika listrik mati BPRS akan mengunakan jenset. BPRS juga memiliki staff dibagian IT, jadi jika ada ganguaan sistem maka IT yang akan menyelesaikanya, misal ada peralatan yang rusak makan akan diganti dengan yang baru dan lebih baik.

Setiap karyawan bersedia dalam bertanggung jawab meminimalisir risiko yang 
akan terjadi sehingga dapat menghindari kerugian yang ada di BPRS. Setiap karyawan telah aware di BPRS Haji Miskin ini, karena semuanya sudah di control dan juga di awasi terhadap kas yang masuk, keluarnya dan berapa antar bank yang dilakukan setiap harinya. Dan membuat laporan pertangung jawaban setiap bulanya ke OJK untuk di control oleh POAC, seperti NPV ya tinggi, CR nya rendah dan itu akan terpantau oleh OJK. Metode BPRS Haji Miskin Pandai Sikek untuk mengetahui risiko-risiko yang kemungkinan terjadi di waktu yang akan datang, BPRS Haji Miskin baru membuat rencana tindak pada tahun 2020 karna aturan baru dari OJK BPRS masih mengunakan metode yang umum dan belum yang khusus. Dengan mengantisipasi sesuai dengan ketentuan-ketentuan yang terjadi, jika di lapangan mesti di catat berapa jumlah uangnya, berapa nominalnya dan juga ada 50 lembar slip yang dibawa kelapangan sudah diberikan nomor, dan berapa slip yang digunakan akan ketahuan dan kalo ada yang salah akan dikembalikan kepada bank. Keterlitian dalam melaksanakan pencatatan karena sudah memakai sistem dan akan terikat di sistem tersebut. Metode terbaik yang paling ekonomis untuk meminimalisir atau mengurangi kerugian dari berbagai sektor di BPRS Haji Miskin Pandai Sikek (misalnya alat teknologi seperti komputer yang digunakan telah rusak sehingga data yang di input hilang) BPRS mempunyai petugas untuk memelihara asset yang mengontrol setiap bulannya asset yang ada di BPRS.

Dalam melakukan estimasi/perhitungan level risiko yang kemungkinan terjadi dimasa mendatang untuk menghindari kerugian karena setiap risiko memiliki nilai. Mulai dari nilai risiko kecil, nilai risiko menegah dan risiko tinggi. Pengelolaan aset jika sewaktu-waktu adanya penurunan reting pendapatan, BPRS Haji Miskin menjaga asset dan meminimalisir biaya-biaya yang ada, penglolaan assetnya seefisien mungkin pemakaiannya dan perawatannya. Dan BPRS pun melihat nilai dari assetnya, jika asset tersebut sudah tidak digunakan lagi maka BPRS menindak lanjuti asset tersebut dengan menjualnya sesuai nilai penyusutan asset tersebut, sehingga BPRS tidak mengalami kerugian. Misalnya Target dalam satu minggu berapa, pendapatan berapa dan dana pihak ketiga berapa karena ada program rencana kerja yang dilakukan. Juga ada komisaris untuk mengevaluasi terhadap rencana kerja tersebut dan juga ada laporan- 
laporan pengawasan yang dilakukan oleh OJK, ada juga dari pihak interen maupun eksteren dari akutan pablik, pengawasan dilakukan oleh dewan komisaris untuk menjalankan fungsinya dalam pengawasan dan juga dewan pengawas syariah menjalankan fungsinya dalam pengawasan syariah.

Pemecahan masalah yang dilakukan terhadap risiko akibat pandemi covid-19, permasalahan yang dihadapi seperti pandemi covid-19 saat ini sehingga nasabah sulit memenuhi kewajiban kredit yang telah jatuh tempo, maka BPRS Haji Miskin memberikan keringanan dengan memperpanjang waktu pelunasan kredit dan mengurangi biaya kewajiban nasabah terhadap denda pinjaman. Dan mengikuti ketentuan yang dilakukan oleh OJK saja, adanya relaksasi, pembiayaan itu jika ada usaha yang terdapak akan lakukan relaksasi karna usahanya tidak dapat membayar sesuai jadwal atau sesuai dengan jumlahnya, kemudian perilaku usaha yang sedang menurun kita lakukan relaksasi juga, pengawasan terhadap usaha tersebut. Mudah-mudahan cepat terhindar dari pandemi yang terjadi, sekarang usaha-usaha sudah bergerak kembali, di pasar-pasar sudah ramai lagi dan juga tidak ada lagi pembatasan sosial berskala besar yang mengakibatkan orang-orang tidak bisa masuk khususnya pada pasar aur kuning sudah mulai bergerak dan daya jual beli sudah mulai meningkat kembali, itulah orang-orang yang terdampak pandemi tersebut. Bagi yang terdampak akan dilakukan rescenduling tentang pembiayaanya, dijadwal ulang sehingga kemampuanya mengecil sehingga otomatis bank antisipasi, dampaknya pendapatan bank akan menurun yang cicilanya biasanya 5 juta sekarang menjadi 1 juta. Inovasinya biasa-biasa saja, tidak ada inovasi yang lebih karena ada aturan main lebih. Asal mengikuti aturan main atau ketentuan yang ditetapkan Insya Allah bisa berjalan dengan baik. Tidak melanggar ketentuan, tidak melanggar undang-undang itu aja prinsip dari perbankan.

\section{PEMBAHASAN}

\subsection{Risiko Operasional yang terdapat di PT Bank Pembiayaan Rakyat Syariah (BPRS) Haji Miskin Pandai Sikek ?}

Berdasarkan hasil penelitian yang telah dilakukan diatas, maka penulis telah melakukan wawancara dengan Bapak Hendri Kamal selaku Direktur Utama BPRS Haji Miskin maka dapat dikelompokan jenis-jenis risiko operasional 
yang terdapat di BPRS ini adalah :

a. Risiko internal, karena adanya kesalahan pada proses pengimputan data oleh karyawan, kesalahan analisis dari marketing, terdapat uang palsu, melakukan pencucian uang. Dimana dijelaskan pada undang-undang No. 8 tahun 2010 tentang pencegahan dan pemberantasan tindak pidana pencucian uang. Pencucian uang adalah segala perbuatan yang memenuhi unsur-unsur tindak pidana sesuai dengan ketentuan dalam undangundang ini (Undang-Undang, Undang-Undang Nomor 8 tahun 2010 tentang Pencegahan dan Pemberantasan Tindak Pidana Pencucian Uang, 2010, p. 1). Bahwa untuk melaksanakan ketentuan pasal 17 ayat (2) uu no 8 tahun 2010 tentang Pencegahan dan Pemberantasan tindak Pidana pencucian uang, perlu menetapkan Peraturan Pemerintah No.43 tahun 2015 tentang pihak pelapor dalam pencegahan dan pemberantasan tindak pidana pencucian uang (Salinan Peraturan Pemerintah, 2015) dan terjadi perubahan pada tahun 2021 pada PP No. 61 Tahun 2021 tentang pe rubahan atas PP No 43 tahun 2015 tentang pihak pelapor dalam pencegahan dan pemberantasan tindak pidana pencucian uang (PP, 2021). Serta didalam Peraturan Otoritas Jasa Keuangan Nomor 12/POJK.01/2017 tentang Penerapan Program Anti Pencucian Uang dan Pencegahan pendanaan Terorisme di Sektor Jasa Keuangan.

b. Risiko Sumber Daya Manusia, di BPRS Haji Miskin terjadinya Fraud karena salah seorang karyawan yang dianggap memiliki kecerdasan dalam mengelola nasabah sehingga pihak BPRS memberikan wewenang besar kepada karyawan yang memberikan kemudahan untuk melakukan berbagai manipulasi transaksi. Akibatnya, karyawan kurang teliti pada saat mengumpulkan data nasabah sehingga perlu kerja dua kali dalam mengumpulkan data nasabah, analisis nilai jaminan yang tidak sesuai. Dalam bidang Sumber Daya Manusia (SDM), manajemen risiko yang dilakukan berupa: bank harus memiliki kode etik yang di berlakukan kepada seluruh pegawai pada jenjang organisasi lalu bank harus menerapkan sanksi secara konsisten pada pegawai yang terbukti melakukan penyimpangan dan pelangaran. (Peraturan Otoritas Jasa 
Keuangan Nomor 18/POJK.03/2016 tentang Penerapan Manajemen Risiko Bagi Bank Umum, 2016) Reduksi risiko operasional yang bersumber dari SDM yaitu untuk mengurangi kemungkinan timbulnya risiko operasional yang berasal dari SDM, kebijakan manajemen risiko bank paling sedikit memuat kebijakan tentang rekrutmen dan penempatan sesuai dengan kebutuhan organisasi, remunerasi dan struktur insentif yang kompetitif, pelatihan dan pengembangan, rotasi berkala, kebijakan perencanaan karir dan suksesi, serta penanganan isi pemutusan hubungan kerja (PKH) dan serikat pekerja. Faktor internal dan eksternal dalam melakukan identifikasi dan pengukuran risiko operasional yaitu antara lain struktur organisasi bank, budaya risiko, manajemen SDM, perubahan Organisasi, dan keluar masuk pegawai (Pedoman Good Corporate Governace Perbankan Indonesia dikeluarkan Oleh Komite Nasional Kebijakan Corporate Governance Januari 2004).

c. Risiko sistem dan teknologi, pada BPRS Haji Miskin yaitu kesalahan yang disebabkan karena adanya ganguan sistem seperti komputer down atau jaringan yang error pada saat pengimputan. Pihak BPRS akan berusaha cepat untuk memperbaiki jaringan melalui vendor dan kesalahan yang disebabkan oleh ganguan komputer down/hang akan diperbaiki oleh IT dari BPRS serta data yang ada sudah di pindahkan atau di simpan pada komputer induk.

d. Risiko hukum

e. Risiko eksternal, kurangnya pengetahuan nasabah akan proses akad serta ketidak sesuaian perhitungan dengan persyaratan syariah. bencana alam yang terjadi sekarang ini yaitu Covid-19. Pihak BPRS melakukan aturan yang dihimbau pemerintah kepada masyarakat dengan mengunakan protokoler kesehatan seperti mencuci tanggan, mencek suhu tubuh dan memakai masker dalam melayani nasabah.

Dampak yang ditimbulkan dari risiko operasional yang mencangkup risiko kepatuhan, risiko hukum dan lain-lain dapat berupa: penarikan besarbesaran terhadap dana pihak ketiga, timbul masalah likuiditas, ijin dicabut oleh Bank Indonesia dan kebangkrutan (Usanti, 2012, p. 425). 
Strategi penanganan dalam mengatasi risiko operasional sudah sesuai dengan POJK No. 18/POJK.03/2016 tentang penerapan manajemen risiko bagi bank umum serta POJK No. 23/POJK/2018 tentang penerapan manajemen risiko bagi Bank Pembiayaan Rakyat Syariah. yang dimana sudah melakukan proses manajemen risiko dimulai dari aktifitas identifikasi, yaitu mengenal dan memehami seluruh risiko yang ada/yang melekat (inherent risks) maupun yang mungkin timbul dari suatu aktifitas bank. Setelah dilakukan identifikasi risiko, selanjutnya dilakukan pengukuran, pemantauan dan pengendalian risiko. Pengukuran risiko yang dimaksud untuk dapat mengukur eksposur risiko yang melekat pada aktivitas bank untuk dapat memperkirakan dampaknya terhadap permodalan yang perlu dipelihara dalam rangka mendukung kegiatan usaha tersebut. Pemantauan risiko dilakukan dengan melakukan evaluasi terhadap ekspours risiko, terutama yang material dan berdampak pada permodalan bank. Hasil evaluasi terhadap ekspour risiko harus dilaporkan tepat waktu, akurat dan informative yang selanjutnya digunakan oleh pihak pengambilan keputusan, termasuk tindak lanjut yang diperlukan yaitu berupa pengendalian risiko antara lain dengan cara penambahan modal, lindung nilai dan teknik mitigasi risiko lainya (Herisman, 2016).

\subsection{Strategi Manajemen Menghadapi Risiko Operasional yang disebabkan} oleh Faktor Internal dan Faktor Eksternal di PT Bank Pembiayaan Rakyat Syariah (BPRS) Haji Miskin Pandai Sikek ?

Strategi manajemen dalam menghadapi risiko operasional dalam faktor internal dan eksternal di BPRS Haji Miskin ada di fungsi pengawasan yang lebih diperketat serta ada internal audit. Strategi yang dilakukan manajemen menghadapi resiko operasional adalah dengan fokus pada 2 faktor tersebut, mengoptimalkan controlling bagi segenap pegawai (internal) dan juga mengoptimalkan controlling bagi nasabah (eksternal). Lalu pihak BPRS akan mengevaluasi dari faktor-faktor yang timbul sehingga menimbulkan risiko operasional yang biasanya dilakukan mingguan maupun bulanan sekali dan akan melakukan internal audit kinerja oleh karyawan yang dipimpin oleh Direksi dan juga dewan pengawas sebelum di lanjutkan ke atas. Cara 

menanggulangi risiko yang terjadi pada umumnya yaitu dengan melakukan pengawasan yang lebih ketat terhadap nasabah dan melakukan edukasi kepada nasabah. Juga memberikan edukasi kepada karyawan, pihak pusat juga akan memonitor dan mereview kepada kantor untuk melakukan pemantauan risiko- risiko yang terjadi.

Misalnya pada risiko operasional, dimana ada kelalaian pegawai melakukan pencatatan, kesalahan posting transaksi kepada core banking system karena karyawan yang ditunjuk kurang berpegalaman, karyawan bank melakukan Fraud, kesalahan analisis dari marketing, nasabah melewati batas waktu pembayaran utang pembiayaan, kurangnya pengetahuan nasabah akan proses pelaksanaan akad, ketidak sesuaian perhitungan dengan persyaratan syariah, terdapat uang palsu, nasabah menggunakan jaminan yang bukan miliknya, nasabah melakukan pembiayaan pada bisnis yang bukan miliknya, nasabah mengancam BPRS karena tidak terima utangnya di tagih.

Dalam mengelola risiko operasional, manajemen wajib memastikan setiap unit kerja menjalani tugas dan fungsinya sesuai prosedur, maka manajemen membentuk pemeriksaan berlapis, mulai dari manajer sampai kepada direktur yang melakukan pemeriksaan terhadap risiko yang terjadi.

\subsection{Kekurangan yang dimiliki BPRS Haji Miskin yaitu:}

BPRS Haji Miskin kedepanya belum tentu akan hidup atau bagaimana dan BPRS tidak memiliki konsultan karena sesuai aturan yang berada pada OJK. BPRS Haji Miskin belum membentuk Satuan kerja khusus untuk menangani resiko/ penanganan eksekutif dan Masih mengunakan metode umum yang khusu untuk meminimalisir resiko-resiko yang terjadi sehingga tidak ada inovasi yang baru dan masih biasa-biasa saja yang dilakukan BPRS.

\section{KESIMPULAN}

Berdasarkan hasil penelitian yang dilakukan penulis di BPRS Haji Miskin Pandai Sikek serta pembahasan yang telah diuraikan, maka dapat diperoleh kesimpulan sebagai berikut:

a. Manajemen risiko operasional BPRS Haji Miskin Pandai Sikek sudah menerapkan manajemen risiko sesuai dengan POJK No. 18/POJK.03/2016 
Strategi Manajemen Menghadapi Risiko Operasional Pada Pt Bank Pembiayaan Rakyat Syariah (Bprs) Haji Miskin Pandai Sikek tentang penerapan manajemen risiko bagi bank umum dan peraturan 0JK No.23/POJK/2018 tentang penerapan manajemen risiko bagi Bank Pembiayaan Rakyat Syariah. Di samping itu BPRS Haji Miskin menerapkan jenis resiko dan yang menjadi resiko utama di BPRS Haji Miskin Pandai Sikek yaitu risiko internal, risiko sumber daya manusia, risiko sistem dan teknologi, risko hukum, dan risiko eksternal.

b. Strategi penanganan risiko operasional pada BPRS Haji Miskin yaitu dengan melakukan proses manajemen risiko dengan aktivitas identifikasi risiko, selanjutnya pengukuran, pemantauan dan pengendalian risiko. Strategi manajemen dalam menghdapi risiko operasional dalam faktor internal maupun ekternal di BPRS Haji Miskin ada di fungsi pengawasan yang lebih diperketat serta ada internal audit.

\section{REFERENSI}

Hamid, A. R. (2008). Lembaga Keuangan Syari'ah. Jakarta: Zikrul Hakim.

Herisman. (2016). Menerapkan Manajemen Risiko Bagi Bank Pengreditan Rakyat (Sesuai Pojk No.13/Pojk.03/2015). Padang: Dpd Perbarindo Sumatera Barat.

Jelita, W. R., \& Shofawati, A. (2019, Februari). Manajemen Resiko Operasional Pada Pt Bank Pembiayaan Rakyat Syariah (Bprs) Jabal Nur Tebuireng Di Surabaya. Manajemen Resiko Operasional, 4(1), 14.

Masrina, I. (2020). Hasil Dari Obervasi Awal Via Chating Bprs Haji Miskin Pandai Sikek. Pandai Sikek: -.

Nurapiah, D. (2019, Juni). Manajemen Resiko Operasional Perbankan Syariah. Eksisbank, 3(1).

Pedoman Good Corporate Governace Perbankan Indonesia Dikeluarkan Oleh Komite Nasional Kebijakan Corporate Governance Januari 2004. (N.D.).

Peraturan Otoritas Jasa Keuangan Nomor 18/Pojk.03/2016 Tentang Penerapan Manajemen Risiko Bagi Bank Umum. (2016).

Peraturan Otoritas Jasa Keuangan, P. (No.1/Pojk.07/2013). Perlindungan Konsumen Sektor Jasa Keuangan. Jakarta: Otoritas Jasa Keuangan.

Pp, S. (2021). Peraturan Pemerintah No 61 Tahun 2021 Tentang Perubahan Peraturan Pemerintah Dalam Pencegahan Dan Pemberantasan Tindak Pidana Pencucian Uang.

Salinan Peraturan Pemerintah, P. (2015). Peraturan Pemerintah Nomor 43 Tahu 2015 Tentang Pihak Pelapor Dalam Pencegahan Dan Pemberantasan Tindak Pidana Pencucian Uang.

Siregar, A. M., Suhaidi, \& Laviza, J. (2014, Februari). Peranan Manajemen Risiko Dalam Tugas Dan Tanggungjawab Direksi Bank Berdasarkan Peraturan Perundang-Undangan Di Indonesia. Usu Law Journal, Ii(No.1), 169-185.

Subekti, W. (2020, February 14). Pengertian Bank Pembiayaan Rakyat Syariah 
Strategi Manajemen Menghadapi Risiko Operasional Pada Pt Bank Pembiayaan Rakyat Syariah (Bprs) Haji Miskin Pandai Sikek (Bprs).

Sukma , W. R., \& Jelita, A. (2019, Februari). "Manajemen Risiko Operasional Pada Pt Bank Pembiayaan Rakyat Syariah (Bprs) Jabal Nur Tebuireng Di Surabaya,". Jurnal Ekonomi Syariah, 4(1), 14.

Undang-Undang. (2010). Undang-Undang Nomor 8 Tahun 2010 Tentang Pencegahan Dan Pemberantasan Tindak Pidana Pencucian Uang.

Usanti, T. P. (2012). Pengelolaan Risiko Pembiayaan Di Bank Syariah. Jurnal Hukum, 3(No. 2), 408-428. 